\title{
ELECTRON MICROSCOPICAL STUDIES ON TRYPANOSOMA CRUZI AND OTHER MICROORGANISMS IN THE REDUVIID VECTOR
}

\author{
PIERRE G. BAUER
}

The relationship between Trypanosoma cruzi and its reduviid vector, discovered by Carlos Chagas (1909), was intensively studied by light microscopy by his student Emmanuel Dias (1934). Dias observed the attachment of the trypanosomes on the rectum and the ampullae of the Malpighian tubes.

Zeledón, Alvarenga \& Schosinsky (1977) presented two transmission electron micrographs, which suggested an adherence of the trypanosome flagella to the hindgut surface by means of hemidesmosomes. Recently two scanning electron microscopical investigations illustrated heavy rectum infections of Triatoma dimidiata and $T$. infestans (Zeledón, Bolaños \& Rojas, 1984; Böker \& Schaub, 1984).

About other microorganisms often encountered in the reduviid bugs, like bacteria (Nyiradi, 1973), no ultrastructural data could be found in the literature. Although viruses have received more attention, especially by Mello and collaborators (see ref. in Mello, 1983).

The present paper presents the results of a transmission electron microscopical study on the interaction of $T$. cruzi with the hindgut region and the ultrastructural analysis of bacterial and viral infections of various bugs.

\section{MATERIAL AND METHODS}

Second nymphal instars of $T$. infestans were infected with Trypanosoma cruzi, Colombiana strain, by feeding them on mice at the peak of their parasitemia. For the bacteria and virus studies, animals of different laboratory colonies of $T$. infestans (originally from Brazil) and $R$. prolixus (originally from Venezuela), fed on guinea pig, pigeon. human or mouse blood, were tested. All the bugs were held at $28^{\circ} \mathrm{C}$ and $70 \%$ rela tive humidity.

Various days after the bloodmeal, the alimentary tract was carefully dissected together with Malpighian tubes and salivary glands and prefixed. overnight at $4^{\circ} \mathrm{C}$, in $6 \%$ glutaraldehyde in cacodylate buffer. After several buffer washings, the material was postfixed in $1 \%$ osmium tetroxide in cacodylate buffer, stained en bloc with $2 \%$ uranyl acctate in $70 \%$ acetone, dehydrated in graded ace tone and propylene oxide and embedded in epon.

$1 \mu \mathrm{m}$ semithin sections were stained with methylene blue/azur II. Ultrathin sections were stained with uranyl acetate and lead citrate or well dried sections were treated for 10 minutes with $5-7 \%$ alkaline bismuth solution (modification, based on Riva, 1974). Carbohydrates were revealed by staining ultrathin sections for 10 minutes with filtered $2.5 \%$ phosphotungstic acid in $0.5 \mathrm{~N} \mathrm{HCl}$, followed by two washings in 2/3N HCl (modification, based on Rambourg, 1971).

\section{RESULTS AND DISCUSSION}

The alimentary tract of the reduviid bug - Fig. 1 shows the different parts of the alimentary tract which were investigated in $T$. infestans and compared with $R$. prolixus (Wigglesworth, 1936; Bauer, 1981). The initial short cardiac midgut part (C). which follows the oesophagus (O) is seldom described in literature. It is larger than in $R$. prolixus, and may sometimes be partly filled with blood. On its sides lie the 2 three-lobed salivary glands (SG), which in $R$. prolixus are reduced to one-lobed principal glands (Baptist, 1941). The cardia precedes the big, bloodmeal storing stomach (S), forming with it the anterior midgut. This is followed by the blood digesting and absorbing intestine (I), which constitutes the posterior midgut. Four Malpighian tubes (MP) lead in to the pylorus by means of large ampullae (A) at the midgut-hindgut limit (Wigglesworth, 1931: Goodchild, 1966). The rectum (R), the main hindgut part, is built as a big sac, which at its entry contains the rectal gland or rectal pad (RG).

Trypanosoma cruzi in the hindgut region of Triatoma infestans - Since the 4 th day after the infective bloodmeal, few small groups of flagellates, adhered by their flagella to the cuticular layer of the rectal gland (Fig. 5) and initial rectal epithelium (Figs. 3, 4, 6; C-zone of Böker \& Schaub, 1984), could be observed in some insects. This indicates that this event can occur earlier than the 8 th or 14 th day as mentioned in other T. cruzi . reduviid bug systems (Zeledón, Bolaños \& Rojas, 1984; Böker \& Schaub, 1984). The flagellar sheath of the adhered trypanosomes was locally expanded and contained a diffuse net of filamentous material (Figs. 4, 5,6). On the inner side of the adhering flagellar membrane of some trypanosomes a low electron dense zone indicated the formation of a hemidesmosomal plaque (Figs. 4,6 ). Mostly cross-sectioned axonemes, comparable to the situation encountered by Zeledon, Alvarenga \& Schosinsky (1977), suggest that the flagella at the adhering zone lie mainly parallel to the gut surface. 


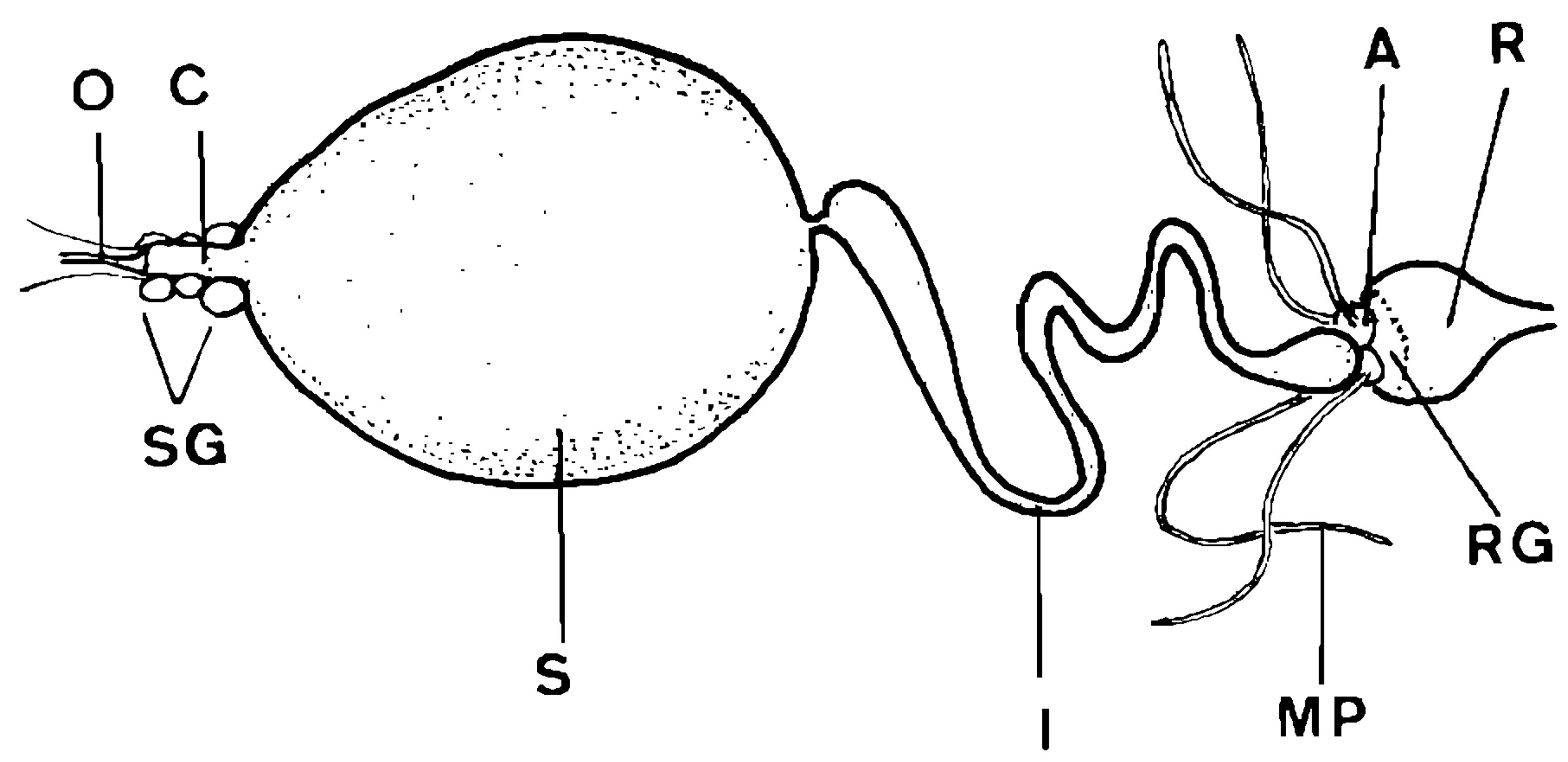

Fig. 1: diagram of the alimentary tract of $T$. infestans (Abbreviations, see in the text).

Invaginations of the plasma membrane at some attachment sites (Fig. 6) may represent pinocytosis (Hommel \& Robertson. 1976) or detachment zones (Brooker, 1971). Sometimes long flagellar extensions were formed to ensure the contact of more distant flagella with the surface of the gut (Fig. 5). The present observations together with the data of Zeledón, Alvarenga \& Schosinsky (1977) indicate that $T$. cruzi attachs to the hindgut of their vectors in the same manner as do other trypanosomatids (Molyneux, 1977). The morphology and location of the kinetoplast in the observed attachment forms identified them as epimastigotes (Fig. 3).

Free flagellates, some in division, were found over the epithelium of the rectum and between rectal foldings (Fig. 7). A few flagellates could also be detected in the lumen of the ampullae of the Malpighian tubes, where some seemed to make contact with the surface of the epithelium (Fig. 2). This interesting zone has only been studied by light microscopy (Wigglesworth, 1931; Lacombe, 1957; Goodchild, 1966) and needs additional ultrastructural investigations. The present observations indicate the existence of different cell types, varving from low epithelial cells with regular microvilli border to typical long, striated ampullae cells with rare microvilli rudiments and drastic cytoplasmic changes. Transitional forms between these two cell types were also detected (Fig. 2). The presence of cells with microvilli in this zone may explain the findings of Sanabria (1966) and Zeledón. Alvarenga \& Schosinsky (1977) of a microvilli bearing region in the rectum. Like Böker \& Schaub (1984) we could only detect cuticle covered epithelium in the whole rectum. The adherence of the trypanosomes with hemidesmosomes between the microvilli of the cells, as shown by Zeledón, Alvarenga \& Schosinsky (1977). Further suggests that they are located in the ampullae because in the microvilli lined midgut. we never could find such a type of trypanosome attachment, even, in higher and older infections and according to Dias (1934) T. cruzi may adhere to the ampullae in the same manner as to the rectum.

Bacteria in the reduviid bug - Rhodnius prolixus of different laboratory colonies generally demonstrated a strong bacterial infection of the gut lumen. In the cardiac midgut part, branched forms could be detected some days after bloodmeal. Their morphology and the carbohydrate staining character of cell wall, mesosomes and polysaccharide granules (Fig. 8) were typical of Nocardia (Farshtchi \& Mc Clung, 1967; Robertson et al., 1975). It is probably Nocardia rhodnii. which is a symbiont of $R$. prolixus (Nyirady, 1973) and represented the main isolate from one bug colony (J.M. Ribeiro, personal communication). In the intestine the predominant bacteria were short rods and cocci. which were partly lysed (Fig. 9).

In one $T$. infestans colony which was maintained for years in close vicinity to a $R$. prolixus culture, only Nocardia rhodnii-like bacteria could be seen (Fig. 13). This confirms earlier observations about the presence of this symbiont in this species of reduviid (Nyiradi, 1973).

Another laboratory colony contained gram positive cocci and short rods, partly in division. inside big vacuoles of some cardia cells (Fig. 10). The wall of the vacuole was formed by microvilli with a more irregular arrangement than those of the cell apex, or the microvilli could be completely missing. Thus far we have not detected any continuity of these vacuoles with the cell surface and so, we are unable to conclude on their intra- or extracellular status. In spite of this problem our data correspond to the earlier light microscopical descriptions of intravacuolar bacteria in midgut cells of $T$. infestans (Dias, 1937; Goodchild, 1955; Halff, 1956). Bacteria could also be found in the gut lumen.

A third $T$. infestans colony, like the first one, presented infections restricted to the gut lumen, but with a different type of gram positive bacteria (Fig. 11). 


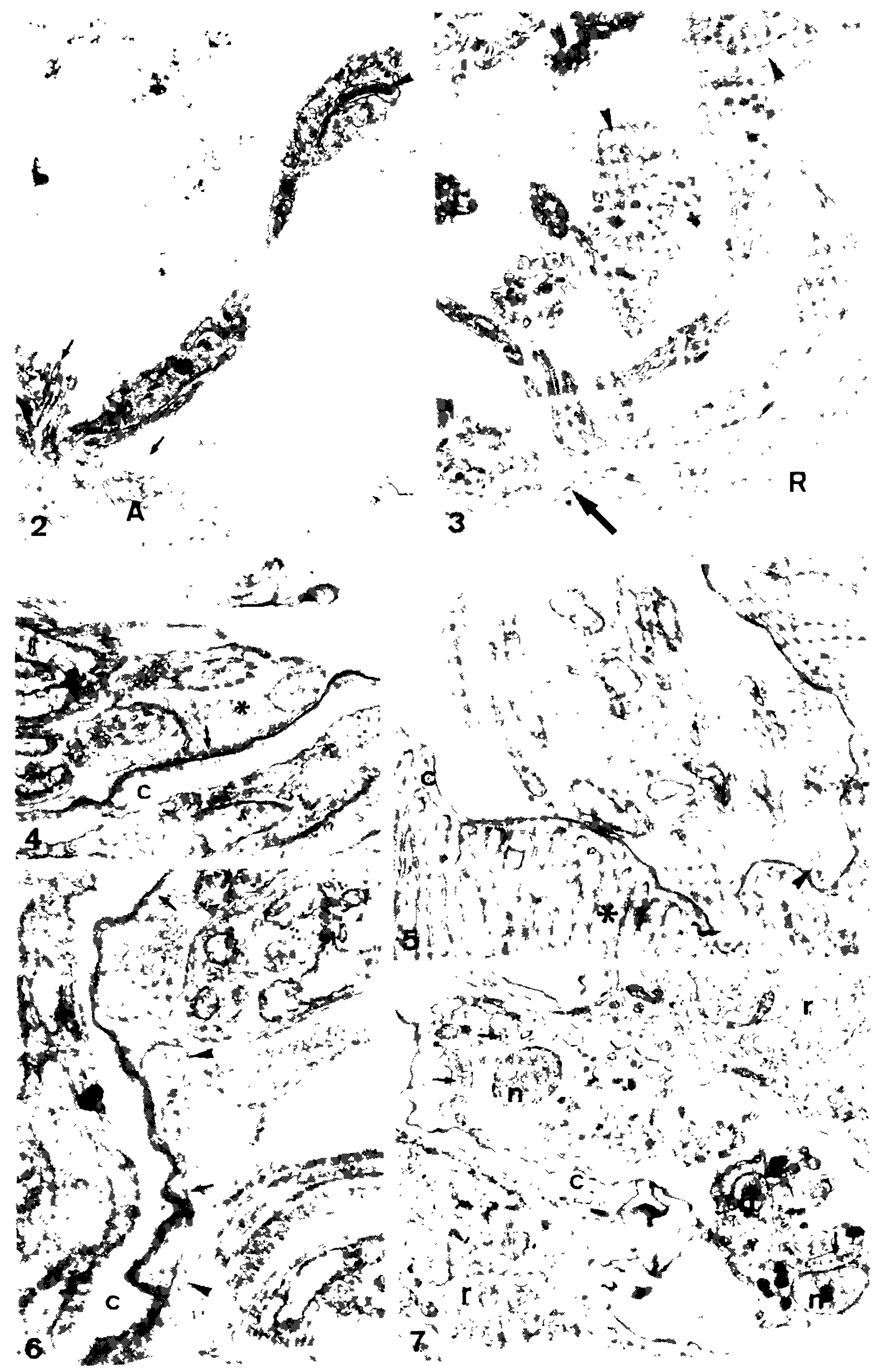

Fig. 2: epimastigote in contact with the irregular microvilli lined surface $(\rightarrow)$ of a transforming cell (A) from the ampulla of a Malpighian tube. $>$ : kinetoplast. $9400 x$. Fig. 3: group of epimastigotes attached to the cuticle $(\rightarrow)$ of the rectum epithelium $(\mathrm{R}) .>$ : kinetoplast. $7000 \mathrm{x}$. Fig. 4: flagella adhered to the rectal surface. The flagellar sheath is expanded and contains filaments ( "). A low electron dense zone inside the flagella at the attachment site $(\rightarrow)$ may represent a hemidesmosomal plaque in formation. c: rectal cuticle. 33000x. Fig. 5 : group of flagella in a folding of the cuticle (c) lined rectal gland with its characteristic apical labyrinth $(*)$. Some flagella present long, filament containing extensions getting in contact with the rectal gland surface $(>)$. 22700x. Fig. 6: flagella attached to the rectum, some presenting membrane invaginations at the attachment site $(>)$. $\rightarrow$ : possible hemidesmosomal plaque in formation. c: cuticular layer. 33000x. Fig. 7: two dividing epimastigotes in a folding formed by the rectal epithelium $(r) . \rightarrow$ : kinetoplast, $n:$ nucleus, $c$ : cuticle. $8800 x$. 
8
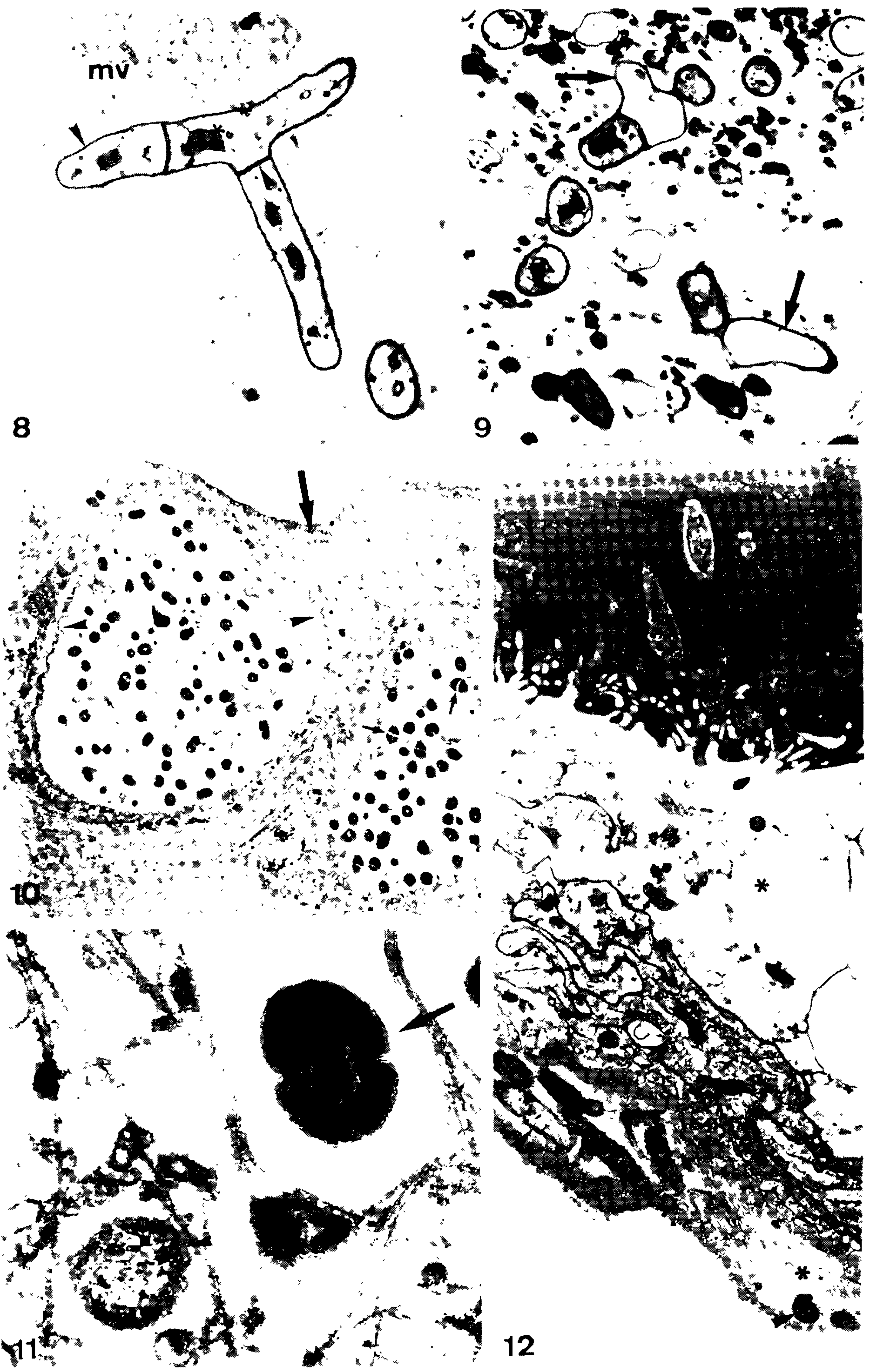

12

Fig. 8: branched Nocardia rhodnii-like bacteria in the cardiac midgut lumen of $\boldsymbol{R}$. prolixus. The carbohydrate stain reveals the cell wall $(>)$, mesosomes $(*)$ and polysaccharide granules $(\rightarrow)$, mv: microvilli of a cardia cell. 16000x. Fig. 9: strong bacterial infection of the intestine lumen of $R$, pro lixus, 21 days after blood meal. The carbohydrate stain facilitates the identification of lysed bacteria $(\rightarrow) .14000$ x. Fig. 10: cardiac midgut cells of a $T$. infestans with vacuoles containing bacteria, partly in division $(\rightarrow)$. The microvilli of the vacuolar border $(>)$ are more irregular than those of the cell apex $(\rightarrow), 3800 x$. Fig. 11: gram positive $(\rightarrow)$ and gram negative (with inner and outer membrane: $>$ ) bacteria in the cardia lumen of a $T$. infestans. 50000x. Fig. 12: gram negative bacteria in $T$. infestans, infecting muscle cells $(\rightarrow)$ and the lumen of the salivary gland $(\rightarrow)$. Relatively empty regions in the cells (*) may indicate pathological changes. $11300 \mathrm{x}$. 

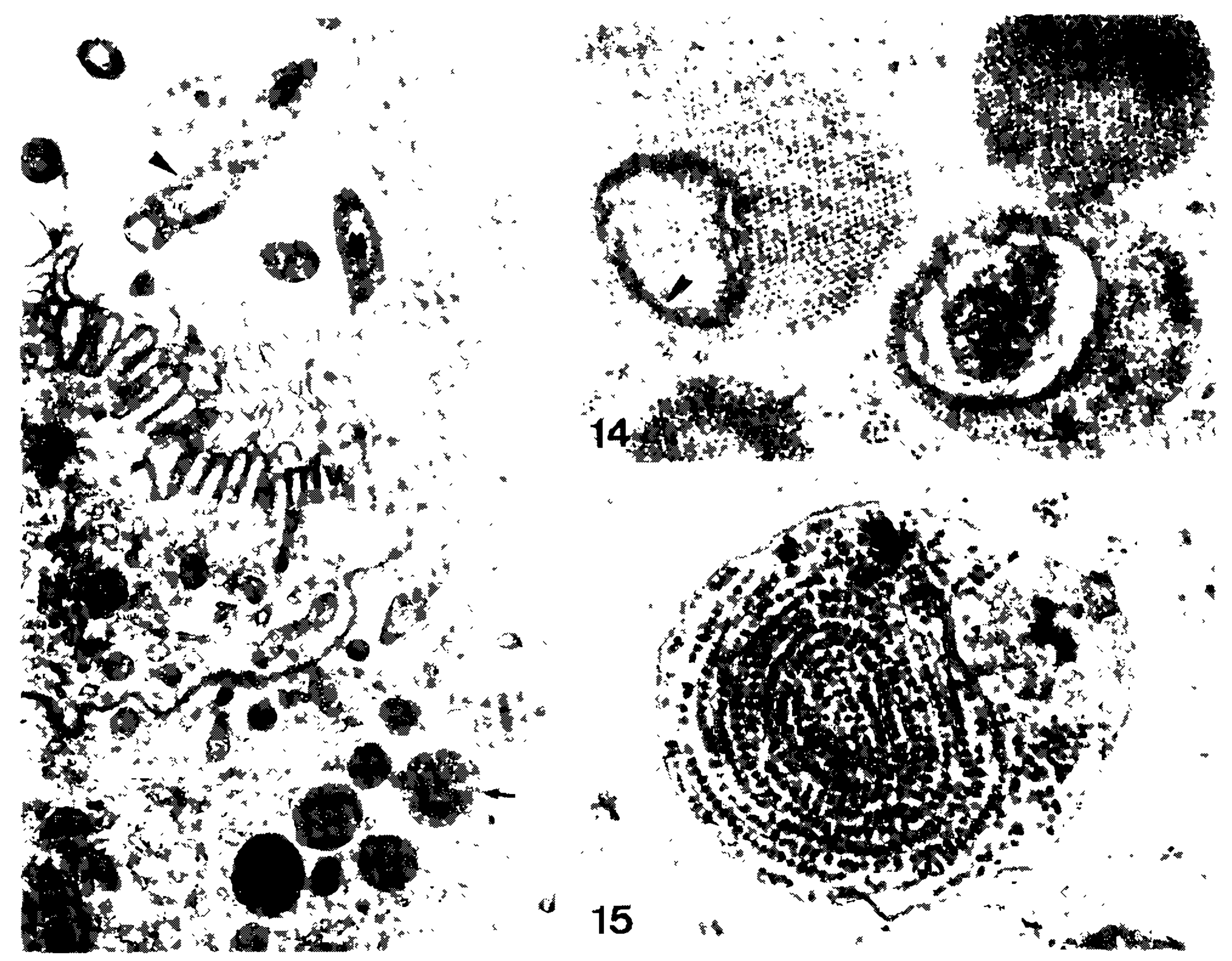

15
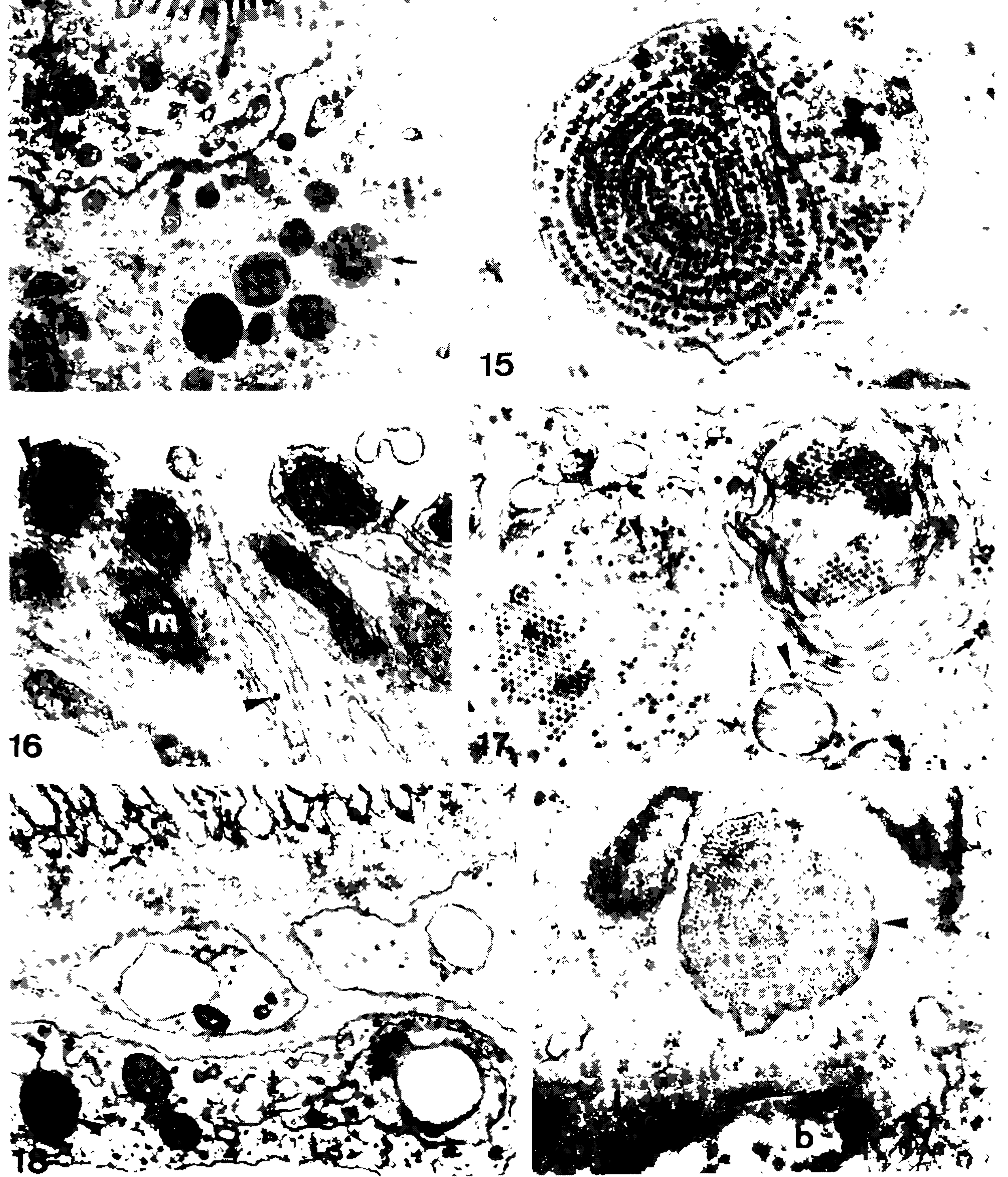

Fig. 13: cardia midgut part of a $T$. infestans. In the lumen: Nocardia rhodnii-like bacteria $(>)$, in the cells; dense round vacuoles, containing viruses $(\rightarrow)$. mv: microvilli. 14000x. Fig. 14: round vacuoles densely packed with paracrystalline arranged viruses and membrane whorls $(>)$ in a cell of the intestine. $41300 \mathrm{x}$. Fig. 15: characteristically arranged viruses between rows of membranes $(\rightarrow)$ in a vacuole of an intestine cell. 57600x. Fig. 16: single viruses $(>)$ in the microvilli of Maipighian tube cells. m: mitochondria. 58500x. Fig. 17: two vacuoles with paracrystalline arranged viruses (*) in a Malpighian tube ccll. Single viruses are present in one vacuole and in the cytoplasm $(\rightarrow), \rightarrow$ : ribosomes. $45500 \mathrm{x}$. Fig. 18: basis of Malpighian tube cells with free viruses in the spaces and at the basis of the basal labyrinth $(\rightarrow)$. A tracheal cell $(t)$ contains a paracrystalline arranged virus complex. (>).33000x. Fig. 19: vacuole with densely packed viruses ( >) and gram negative bacterium (b) in digestion by a lysosome ( 1 ) inside a salivary gland cell. $35800 \mathrm{x}$. 
All three $T$. infestans colonies examined were infected with gram negative rods. The differentiation between gram positive and gram negative was possible at the ultrastructural level by the analysis of the cell wall structure (Fig. 11; Sleytr, 1978). The second and third colonies sometimes showed gram negative bacteria in the gut lumen together with the gram positive ones previously described (Fig. 11). Generally the gram negative bacteria occured outside the gut, in hemocytes, nerve axons, muscle cells and salivary glands (Fig. 12). Various bugs presented a salivary gland lumen infection (Fig. 12). Some cytoplasmatic changes in infected organs suggested possible pathologic effects, of the bacteria (Fig. 12), while in other cells a lysosomal elimination of the bacteria could be observed (Fig. 10). These results demonstrate that, like with rickettsia-like microorganisms of Triatoma rubrofasciata (Webb, 1940), bacteria may be localized outside of the reduviid gut. Furthermore the diversity of bacteria occuring in $T$. infestans could be confirmed (Nyirady, 1973).

The various bloodmeal types probably did not influence the bacterial flora in $R$. prolixus, while the observed variety in $T$. infestans may be due to the different origins of the laboratory colonies or to the different hosts on which they were fed, as already found by Rondinone et al. (1978).

Some of the $R$. prolixus and $T$. infestans did not show bacteria, which may be due to insufficient contamination in the rearing jars (Brecher \& Wigglesworth, 1944).

The identification of the bacteria is necessary, because among gram positive cocci and gram negative rods, al ready isolated from $T$. infestans, potentially human pathogens, like Staphylococcus albus, St. aureus, Alcaligenes faecalis, Enterobacter cloacae and Klebsiella pneumoniae, were present (Goodchild. 1955; Rondinone et al., 1978). Furthermore, experimental infections demonstrated that among various Nocardia species, the human pathogen Nocardia asteroides (Beaman et al., 1976) could also evolve in $R$. prolixus (Nyiradi, 1973).

Dias (1934), Mühlpfordt (1959) and Jadin (1967) found that bacteria could reduce the T. cruzi infection in Panstrongylus megistus, $R$ prolixus, and $T$. infestans respectively. Studies about this relationship are now under investigation and first results seem to confirm Mühlpfordt's observation about the inhibiting effect of Nocardia rhodnii on strain Y of $T$. cruzi some weeks after the infective bloodmeal. The opposite effect in the first days may partly be explained by the observed reduction of the bacterial flora in the intestine after a bloodmeal and its reinfestation only after about 1 week. On the other hand, in other systems, the trypanosome seem to inhibit bacterial growth.

Viruses in the reduviid bug - Small viruses $(20-30 \mathrm{~nm})$, partly in paracrystalline arrangement, were detected in lysosome-like vacuoles of the cells of the midgut (Figs. 13, 14, 15), Malpighian tubes (Fig. 17), tracheal ceils (Fig. 18) and salivary glands (Fig. 19) of some T. in festans. Single viruses could be identified in the cytoplasm of Malpighian tube cells (Fig. 17), partly inside the microvilli (Fig. 16) and also extracellularly between the foldings of the basal labyrinth (Fig. 18). Differentiation from the similarly looking ribobomes was of ten possible due to the more regular, round form and somewhat larger diameter of the single viruses (Fig. 17).

This small virus most probably corresponds to the one described by Dolder \& Mello (1978) in $T$. infestans and $P$. megistus. They identified it with cytochemical tests as RNA-virus. Its size suggests that it belongs to the small RNA-viruses of insects (Moore \& Tinsley, 1982) or to the Picornaviridae of vertebrates, which contain several human pathogenic species (Wiesmann, 1982).

Further electron microscopical descriptions of viruses from reduviids include a $30-40 \mathrm{~nm}$ RNAvirus in the cells and lumen of the salivary glands of $T$. infestans (Mello, 1983) and rhabdovirus-like particles in the fat body of a Trypanosoma rangeli infected Rhodnius neglectus (Kitajima, Cuba Cuba \& Brener, 1978).

Studies on natural and/or experimental infections with various arboviruses (Justines \& Sousa, 1977), hepatitis B (Villarejos, Zuniya \& Gutierrez, 1975; Candeias, Forattini \& Vieira, 1976) and various oncogenic viruses (Rehacek, Fischer \& Luecke, 1976) suggest some role for the reduviid bugs in virus transmission.

The bacteria and possible virus infestation of the reduviid vector is mostly overlooked in xenodiagnostical and epidemiological studies. The presence of these microorganisms in the lumen of the salivary glands of several $T$. infestans may have medical implications. Part of the severe reactions after the bite of bugs (Dias, 1968) and perhaps some chagoma may be due to such organisms. Bambirra et al. (1984) demonstrated a significant increase of the reactivity of mice to the lethal effect of lipopolysaccharides of gram negative bacteria during a $T$. cruzi infection. The presence of human pathogenic bacteria and viruses in reduviid bugs could also influence the pathologic picture in Chagas' disease.

The use of germfree bugs, fed on suitable hosts (Nyirady, 1973), may be indicated for xenodiagnosis, with the additional advantage of the lack of possible inhibitory effects of some bacteria on $T$. cruzi.

On the other hand, the heavy infection of various organs of the bug by small RNA-viruses and gram negative bacteria may indicate them as possible candidates for biological control of the reduviid vector. The detection of natural pathogenic agents in the bug is an important task for the fight against Chagas' disease. 


\section{ACKNOWLEDGEMENTS}

I wish to express my gratitude to many colleagues in Brazil, Germany and Switzerland for their help with material and useful discussions. Special thanks to Dr. Maria P. Deane for the invitation to participate at this symposium, and to her and Dr. Henrique Lenzi for the critical reading of the paper, to Dr. Gabriel Grimaldi and his crew for the facilitations received to develop the present study in the Electron Microscope Center, and to my lovely wife for drawing the gut diagram.

\section{REFERENCES}

BAMBIRRA, E.A.; CRUZ, M.Q.D.; CAMPOS, D.S. \& LIMA, A.O., 1984. Some characteristics of the hyperreactivity to bacterial lipopolysaccharide induced in mice by Trypanosoma cruzi infection. Mem. Inst. Oswaldo Cruz, $79: 433-437$.

BAPTIST, B.A., 1941. The morphology and physiology of the salivary glands of Hemiptera-Heteroptera. Quart. J. Micr. Sci., 83 :91-139.

BAUER, P.G., 1981. Ultrastrukturelle und physiologische Aspekte des Mitteldarms von Rhodnius prolixus. Ph.D. thesis. Univ. Basel.

BEAMAN, B.L.; BURRSIDF, J.; EDWARDS, B. \& CAUSEY, W., 1976. Nocardial infections in the United States, 19721974. J. Infect. Dis., $134: 286-289$

BÖKER, C.A. \& SCHAUB, G.A., 1984. Scanning electron microscopic studies of Trypanosoma cruzi in the rectum of its vector Triatoma infestans. Z. Parasitenkd., $70: 459-469$.

BRECHER, G. \& WIGGLESWORTH, V.B., 1944. The transmission of Actinomyces rhodnii Erikson in Rhodnius prolixus Stal (Hemiptera) and its influence on the grow th of the host. Parasitology, $35: 220-224$.

BROOKER, B.E., 1971. Flagellar attachment and detachment of Crithidia fasciculata to the gut wall of Anopheles gambiae. Protoplasma, $73: 191-202$.

CANDEIAS, J.A.N.; FORATTINI, O.P., \& VIEIRA, J.G., 1976. Evidenciação de antigenos da hepatite B (HBsAg) em "manchas" obtidas de exemplares de Triatominae. Rev. Saúde Públ., S. Paulo, 10 :267-268.

CHAGAS, C., 1909. Nova tripanosomiase humana. Estudos sobre a morfologia e o ciclo evolutivo de Schizotrypanum cruzi. Mem. Inst. Oswaldo Cruz, $1: 159-218$.

DIAS, E., 1934. Estudos sobre o Schizotrypanum cruzi. Mem. Inst. Oswaldo Cruz, 28 :1-110.

DIAS, E., 1937. Sobre a presença de symbiontes em Hemipteros hematophagos. Mem. Inst. Oswaldo Cruz, $32: 165-168$.

DIAS, J.C.P., 1968. Manifestaçōes cutâneas na prática do xenodiagnóstico. Rev. Bras. Malariol. Doenças Trop., 20 :247257.

DOLDER, H. \& MELLO, M.L.S., 1978. Dados preliminares sobre partículas semelhantes a virus em células de Triatomíneos. Rev. Saúde públ. S. Paulo, 12 :104-109.

FARSHTCHI, D. \& MC CLUNG, N., 1967. Fine structure of Nocardia asteroides grown in a chemically defined medium. J. Bacteriol., $94: 255-257$.

GOODCHILD, A.J.P., 1955. The bacteria associated with Triatoma infestans and some other species of Reduviidae. Parasitology, $45: 441-448$.

GOODCHILD, A.J.P., 1966. Evolution of the alimentary tract in the Hemiptera. Biol. Rev., $41: 97-140$

HALFF, L.A., 1956. Untersuchungen über die Abhängigkeit der Entwicklung der Reduviide Triatoma infestans Klung von ihren Darmsymbionten. Acta trop., $13: 225-253$.

HOMMEL, M. \& ROBERTSON, E., 1976. In vitro attachment of trypanosomes to plastic. Experientia, $32: 464-466$.

JADIN, J., 1967. Du rôle des bactéries dans le tube digestif des insectes vecteurs des plasmodidae et des trypanosomidae. Ann. Soc. belge Méd. trop., $47: 331-342$.

JUSTINES, G. \& SOUSA. O.E., 1977. Survival of arboviruses in trypanosome-infected triatomines. Am. J. Trop. Med. Hyg., $26: 326-328$.

KITAJIMA, E.W. ; CUBA CUBA, C.A. \& BRENER, Z., 1978. Tryponosoma rangeli na glândula salivar do barbeiro Rhod nius ecuadoriensis. V. Reuniāo Anual, Pesquisa Básica em Doença de Chagas, Caxambú - MG, B-40.

LACOMBE, D., 1957. Estudos anatômicos e histologicos sôbre a subfamilia Triatominae (Heteroptera, Reduviidae). VII. Estudo anatômico do ducto intestinal do Triatoma in festans. Mem. Inst. Oswaldo Cruz, $55: 69-111$.

MELLO, M.L.S., 1983. Cy toplasmic inclusions in virus-infected salivary gland cells of Triatoma infestans Klug. Rev. Brasil. Biol., $43: 251-256$.

MOLYNEUX, D.H., 1977. Vector relationships in the Trypanosomatidae. Adv. Parasitol., 15:1-82.

MOORE, N.F. \& TINSLEY, T.W., 1982. The small RNA-viruses of insects. Arch. Virol., $72: 229-245$.

MÜHLPFORDT, H., 1959. Der Einfluss der Darmsymbionten von Rhodnius prolixus auf Trypanosoma cruzi. Z. Tropenmed. Parasitol., $10: 314-327$.

NYIRADY, S.A., 1973. The germfree culture of three species of Triatominae: Triatoma protracta (Uhler), Triatoma rubida (Uhler) and Rhodnius prolixus Stal. J. Med. Ent., $10: 417-448$.

RAMBOURG, A., 1971. Morphological and histochemical aspects of glycoproteins at the surface of animal cells. Int. Rev. Cytol., $31: 57-114$.

RHHACEK, J.; FISCHER, R.G., \& LUECKE, D.H., 1976. Oncogenic viruses in vertebrates transmitted by hematophagous arthropods. Adv. Virus Res., $20: 159-188$ 
RIVA, A., 1974. A simple and rapid staining method for enhancing the contrast of tissues previously treated with uranyl acetate. J. Microscopie, $19: 105-108$.

ROBERTSON, J.G.; LITTLETON, P.; WILLIAMSON, K.I. \& BATT, R.D., 1975. The effect of fixation procedures on the electron density of poly sacharide granules in Nocardia corallina. J. Ultrastruct. Res., $50: 321-332$.

RONDINONE, S.N.; ISOLA, E.L.D.D.; VILLAFURTE, M.C.; SANCHEZ, D. \& FRIGERIO, M.J., 1978. Flora bacteriana intestinal del Triatoma infestans. Rev. Asoc. Arg. Microbiol., $10: 117-124$.

SANABRIA, A., 1966. Ultrastructure of Trypanosoma cruzi in the rectum of Rhodnius prolixus. Exp. Parasitol., 19 :276299.

SLEYTR, U.B., 1978. Regular arrays on bacterial ccll walls. Int. Rev. Cytol., 53 :1-64.

VILLAREJOS, V.M.; ZUNIYA, A. \& GUTIERREZ, A., 1975. Possible role of haematophagous insects in transmission of type B hepatitis. Trans. R. Soc. trop. Med. Hyg, $69: 368-369$.

WEBB, J.L., 1940. The occurence of rickettsia-like bodies in the reduviid bug Triatoma rubrofasciata and their transmission to laboratory animals. Parasitology, $32: 355-360$.

WIESMANN, E., 1982. Medizinische Mikrobiologie. Georg Thieme Verlag, Stuttgart/New York.

WIGGLESWORTH, V.B., 1931. The physiology of excretion in a bloodsucking insect, Rhodnius prolixus (Hemiptera, Reduvidae. II. Anatomy and histology of the excretory system. J. Exp. Biol., $8: 428-442$.

WIGGLESWORTH, V.B. 1936. Symbiotic bacteria in a blood-sucking insect, Rhodnius prolixus Stal (Hemiptera, Triatomidae). Parasitology, $28: 284-289$.

ZELEDON, R.; ALVARENGA, N.J. \& SCHOSINSKY, K., 1977. Ecology of Trypanosoma cruzi in the insect vector. In: Chaga's' disease. Symposium of the Pan American Health Organization. Sci. Publ. No. 347, p. 59-70.

ZELEDÓN, R.; BOLAÑOS, R., \& ROJAS, M. 1984. Scanning electron microscopy of the final phase of the life cycle of Trypanosoma cruzi in the insect vector. Acta trop., $41: 39-43$. 